\title{
Italian Futurism in Russian Poetry: Vladimir Mayakovsky's Poetic Revolution
}

\author{
Katherine Anna New \\ New College, University of Oxford, Great Britain, \\ Address: New College, Holywell St, Oxford OX1 3BN \\ This work was supported by an AHRC research grant
}

\begin{abstract}
The aim of the present article is to analyse the reception of the poetic principles of Italian Futurism in the works of the most famous Russian Futurist poet, Vladimir Mayakovsky. The author of the article tracesthe change of hisartistic views and its impact on the development of his self-representation. Mayakovsky's poetic selfidentification divides into two stages, which are influenced by personal, social and political factors of his time. In his pre-revolutionary works, the poet's self-identity is marked by intense loneliness and despondency arising from his protest against the bourgeois and the dreariness of mundane life. Mayakovsky's early poetry follows the programmes formulated by Italian and Russian Futurists, such as the demolition of traditional art, revolt against poetic canons, disrespect for acknowledged masters of lyrical verse (primarily Pushkin), denial of the established semantics of lexical units, destruction of poetic vocabulary, disassociation of metaphors. During the second stage of his development as a poet, Mayakovsky represents himself through a persona engrossed in the interests of the post-revolutionary community and the new state: the feeling of loneliness is ousted by the sense of solidarity with the nation creating a new civilization; despondency gives way to the feeling of self-fulfillment. Mayakovsky's new self-identity as a revolutionary corresponds to his revolutionary changes of both the semantics and the structure of Russian verse: heintroduces original themes into poetry (praising the revolution, glorifying the new socialist order); he pioneers the art of poetic propaganda, relating verbal art to the acts of sanitation and physical toil. In the poems belonging to the second period, Mayakovsky gradually departs from the canons of Futurism, shows admiration for Pushkin and seeks to establish an intertextual poetic dialogue with the most renowned of the Russian poets.
\end{abstract}

Key words: Mayakovsky, Marinetti, Futurism,self-identification, persona, metaphor.

The term 'Futurism', derived from the Latin word 'futurum' meaning 'future', is used to denote a European artistic movement of the $20^{\text {th }}$ century, thought to have originated in Italy, which comprised a total break from tradition in favour of new forms (Lynton 1994: 90-97). An Italian poet, Filippo Tommaso Marinetti, in his 'Manifesto on Futurism' stated that the Futurists saw fighting against old art as their goal: 'up to now literature has exalted a pensive immobility, ecstasy and sleep. We intend to exalt aggressive action, a feverish insomnia, a racer's stride, a mortal leap, a punch, the slap' (Marinetti 1911). The call for aggressive actions, expressed in the seventh statute of Marinetti's 'Manifesto': 'There is no masterpiece that has not an aggressive character. Poetry must be a violent assault on the forces of the unknown, to force them to bow before man' (Marinetti 1911), and the demand to give a 'slap' to the whole of existing artistic tradition was not only adopted but also became a necessary requirement among Russian Futurists.

In Russia, the Futurist movement appeared in 1911 and branched into several sub groups, most notably the Egofuturists (represented by Igor Severyanin, Petr Larionov, Georgii Ivanov, Konstantin Olimpov), cultivating egocentricity, refinement of perception and the use of neologisms of foreign origin), and the Cubo-futurists, consisting of David Burlyuk, Vladimir Mayakovsky, Vasiliy Kamenskii, Velimir Khlebnikhov, Alexey Kruchenykh and Elena Guro (Альфонсов 1999: 5-66; Матюшин 1989: 129-158). The Cubo-futurists, whose movement combined the French principles of Cubism with Italian Futurist poetics, sought to reform art in the same way as revolutionaries had transformed the state (Михайлов 1990: 46). Their intention was to negate and refute both traditional canons and the philistine, bourgeois society of their time. As a movement, Futurism (like Acmeism) superseded Symbolism, which the Futurists found outdated because of its lack of political aspirations. Although the adherents of Russian Symbolism, such as Valeriy Bryusov, Konstantin Balmont and Dmitriy Merezhkovsky, rejected the bourgeois way of life, their artistic principles were conditioned by the tendency to symbolic expression of the hidden realia of daily life, which necessarily limited the connection between poetry and society(Михайлов 1990: 47).Futurism, on the other hand, had distinctly democratic elements, which brought the art of poetry closer to the every-day realities of the 20th century and had distinct 'socialist colouring' (Михайлов 1990: 47). Their aims were formulated by the Futurist painters Kazimir Malevich and Mikhail Matyushin in an interview to the journal Theatre and Life: 'Futurists want to free themselves of the orderliness of the world and from all the connections which were thinkable in it. 
They want to turn the world into chaos, to break all established values to pieces and to create new values from the fragments, making new generalizations, discovering new, unexpected and invisible links'(Иванов 1996: 172). As pointed out by Futurists themselves, the destructive goals of their movement were no less significant for them than their creative programme.

Establishing statutes and principles of the new movement was one of the aims of Vladimir Mayakovsky's earliest activity, arising from his recognition that Futurism in Russia was an unfocussed movement, lacking unity and precise definition ('Futurism as a united precisely formulated movement did not exist in Russia before the October Revolution', Mayakovsky’s letter on Futurism, Moscow, 1 September 1922) (Маяковский 1922: 56). In coauthorship with David Burlyuk and Alexey Kruchenykh, Mayakovsky composed a manifesto, 'A Slap to the Public Taste' ('Пощечинаобщественномувкусу', 1912), which was followed by a number of similar texts with highly meaningful titles, 'Theatre, Cinema, Futurism' ('Театр, кинематограф, футуризм', 1913), 'Gotohell!' ('Идитекчерту!' 1914), 'ADropofTar' ('Каплядегтя', 1915)', 'AManifesto of the Flying Federation of Futurists'

('Манифестлетучейфедерациифутуристов', 1918). Each of these manifestos was based on the most fundamental principles of the Futurists' aspirations: rebellion against established artistic traditions, rejection of previous cultural, poetic, stylistic and linguistic canons and an attempt to direct art towards the future (Terras 1985: 162).

The Futurists' manifesto 'A Slap to the Public Taste' (1912) whose title was most likely influenced by Marinetti's intention 'to exalt aggressive actions', including slaps, contained a concise outline of the Russian Futurists' views. The degree of self-confidence is demonstrated in both the style and the content of the document. Its authors 'order' that their rights as poets should be respected, using a word endowed with imperative connotations, surprising in a group so open to the democratic principles ('We order that the rights of poets should be respected'). The authors contrast themselves to their surroundings, from which they shrink and which rejects them ('With horror we remove from our proud brow the garland of cheap glory made by you of sauna birch twigs... standing on the rock of the word 'we' among the sea of whistles and indignation'). In these declarations, the Futurists appear to be combining their self-identification as rejects from society who have no place among ordinary people with a certain degree of relishing their unique and solitary originality ('on the rock'... 'among the sea'). Maintaining the Futuristic preoccupation with human individuality, Mayakovsky exaggerates the emphasis on himself in his poetry, and like the Futurists in the manifesto 'A Slap to the Public Taste', compares himself to those surrounding him, who are unable to do what he can or to escape the anonymity of an unthinking 'crowd'. The poet attempts to signify his own artistic potential in his poem 'And would you be able?' (‘А вы могли бы?’): ‘А вы / ноктюрн сыграть / могли бы / на флейте водосточных труб?', 'And would you be able to play a nocturne on the flute of the drain-pipes?', in which he emphasises that his lyrical hero is able to view an object of everyday utility, such as a drain pipe, as something endowed with great artistic potential, a musical instrument with the help of which he alone can play a beautiful melody. Mayakovsky challenges 'you', a term of address deliberately open-ended and so implying 'anyone', to do the same and ends the poem on an elliptical note, signifying a negative answer to the question formulated in the title.

In their manifesto 'A Slap to the Public Taste' Mayakovsky and his co-authors rejected all the aesthetic values of former centuries and proclaimed a complete break with all preceding literary traditions, announcing that 'the past was constrictive'. The Futurists stated that only their own art reflected the needs of contemporary epoch ('Толькомы - лицонашегоВремени') and declared that 'Pushkin is less comprehensible than hieroglyphs', demanding that all classic writers such as 'Pushkin, Dostoevsky and Tolstoy should be thrown from out of the Ship of Modernity' ('БроситьПушкина, Достоевского, Толстогоипроч. ипроч. сПароходаСовременности').Тhеу claimed that books written by 'innumerable' traditional authors, such as Leonid Andreev, were 'polluted with a dirt which had to be scrubbed clean from the hands of modern readers' and expressed a belief that they were superior to the old, classical writers and 'observed universal nonentity from the height of their skyscrapers'. A metaphor linking a poet and a skyscraper reflects the Futuristic cult of urbanisation and industrialisation, which was proclaimed in Marinetti's manifesto, glorifying modern capitals with their railway stations, factories, steamers, locomotives and aeroplanes.

In keeping with Futurist poetics, Mayakovsky seconds his declarations in his own poetry. In a poem with the expressive title, 'Fed up' ('Надоело', 1916), he extends the list of classical Russian authors (started in 'A Slap to the Public Taste') to those for whom he feels special aversion and complains of their tediousness: 'Не высидел дома. / Анненский, Тютчев, Фет. / Опять, / тоскоюклюдямведомый, / идувкинематографы, втрактиры, вкафе', 'Icould not stayathome. / Annensky, Tyutchev, Fet. / Again drawn by longing for people, / I am going to cinemas, taverns, cafes'. Mayakovsky's choice of authors' names in his poem 'Fed up' can hardly be accidental. He lists the most refined Russian lyrical poets of his time: Innokenty Annensky, a subtle lyric poet and playwright, Classical scholar, translator of Ancient Greek tragedies, a guru for Russian Acmeists; Fedor Tuytchev, the author of the most profound philosophical lyric poetry and a translator of Latin verse, especially Horace, a teacher of Russian Symbolists; Afanasii Fet, 
One of the finest lyrical poets, a subtle idealist, a Russian Parnassian and a translator of Virgil'sAeneid. It is hard not to notice that each of the poets Mayakosky names was not only among the most talented lyrical poets but also had enormous influence on poetic movements (acmeists, symbolists) and was professionally interested in Classical Antiquity. Mayakovsky may have inherited his denial of Classical culture from the Italian Futurists, who also aggressively denigrated Classical Antiquity (cf. in Marinnetti's Manifesto : 'We want to demolish museums and libraries, fight morality $\langle\ldots>$ we want to deliver Italy from its gangrene of professors, archaeologists, tourist guides and antiquaries'; 'a roaring motor car which seems to run on machine-gun fire, is more beautiful than the Victory of Samothrace'). Like Marinetti, Mayakovsky contrasts authors of the highest lyrical poetry, who dedicated their lives to the study and translation of Classical Antiquity (both Greek and Latin) and had the greatest influence on the development of Russian literary traditions, with the most popular kinds of public entertainment, cinemas, taverns, cafes, stating that he prefers the latter to the former (cf. inMarinetti's Manifesto 'a roaring motor car $<\ldots>$ is more beautiful' than the finest sculpture of all times, 'the Victory of Samothrace'). Thus Mayakovsky closely follows Italian Futurism in his declaration of a conscious break with high culture and art, both contemporary and Classical, and in his proclamation of love for common people and popular tastes.

Although the Russian Futurists shared their artistic views with Italian poets, they not only rejected the heights of Classical and Russian culture but also the poetic geniuses of the Italian Renaissance, Dante and Petrarch. In Mayakovsky's poem 'To His Own Beloved Self the Author Dedicates These Lines' ('Себе любимому посвящает эти строки автор', 1916) Dante and Petrarch are called 'tongue-tied' for their single-minded love for Beatrice and Laura respectively: 'Еслиббытьмнекосноязычным, / какДант / илиПетрарка!', 'if I was so tongue-tied, as Dante or Petrarch'. Mayakovsky expresses his feeling of superiority over Italian Renaissance poets and his belief in his own spiritual freedom and monumentality: '... Дант / илиПетрарка! / Душукоднойзажечь! / Стихамивелетьистлетьей! / Ислова / илюбовьмоя - / триумфальнаяарка: / пышно, / бесследнопройдутсквозьнее / любовницывсехстолетий', 'Dante / or Petrarch! / To ignite a soul with the love for one! / To make it smoulder in verse! / Both my words / and my love / is a triumphant arch: / opulently, / without trace will pass through it / the mistresses of all centuries'. Mayakovsky draws a comparison between himself and Dante and Petrarch, who could only sing of their love for one woman, and states that his own 'opulent' verse wouldcondemn to anonymity the mistresses of other lovers across all time. The art of the Italian Renaissance, deemed immaterial by Mayakovsky, is contrasted with his own 'triumphal arch' (a poetic allusion to a most famous phenomenon of Roman architecture, dedicated by victorious generals returning to Rome with their spoils) which he has power to erect with his words and which will commemorate his love and make him forever immortal. As can be seen from the title of the poem, 'To His Own Beloved Self the Author Dedicates These Lines', Mayakovsky, unlike Dante and Petrarch, who immortalised their beloved, viewed his own personality as worthy of being the sole object of his superior verse.

The rejection of the old in favour of the new, which Mayakovsky shared with the Italian Futurists, was tightly linked to the new socialist order. The Russian Futurists characterised themselves as revolutionaries of art, stating that they had the same legacy as political revolutionaries, more specifically the same as the participants in the 1917 February Revolution, who, by their activity, marked the dawn of a new, greater era. Mayakovsky made the comparison explicit in his 'Manifesto of the Flying Federation of Futurists' ('Манифест летучей федерации футуристов', 1918) by drawing parallels between the February revolutionaries, who as individuals, overcame political slavery (stating that 'the old regime stood on three whales, political slavery, social slavery and spiritual slavery'), and the proletariat who were called to overcome spiritual slavery ('The February revolution destroyed political slavery. We, the proletariats of art, are calling the proletariats of factories and lands to the third bloodless but severe revolution, the revolution of spirit'). By exhorting the people to join him in his movement against spiritual slavery and the stifling traditions of the past, Mayakovsky was urging the futuristic programme of defying the old and breaking boundaries in search of freedom.

The founder of Russian Cubo-futurism, David Burlyuk called on his contemporaries for protest and rebellion: 'We, the revolutionaries of art, mustbreak into the life of streets and squares, we must carry the protest and the call 'Barge-haulers, clear off!' everywhere. From now on our delight should be to shock the bourgeois ('épater les bourgeois'). Let Mayakovsky's top-hat and our harlequin clothes be disgusting to all middlebrows. More mockery for the petty bourgeois scum! We must paint our faces and instead of roses put peasants' wooden spoons into our buttonholes'(Каменский 1931: 170). Using Mayakovsky's extravagant appearance as an example, David Burlyuk expresses the Futurist concept of revolution (or rather riot) against everything: customary norms of behaviour, commonly accepted appearance, colloquial style of speech, the views of the bourgeoisie, of the philistines, of all ordinary members of society. The slogan, which Burlyuk asks the Cubo-futurists to adopt, 'Сарынь на кичку!', further highlights their self-identification as warriors who must fight to prove their rights. Historically this slogan could have been a war-cry used by Cossacks in battle (Северская 2010), which was borrowed from the Polovetzian exhortation 'Sary o kichkou!', 'Сары о кичкоу!' (Polovtzy, ahead!') or alternatively 'Saryn kjochchak!' Сарын къоччакъ! (in Old Turkish, 'Glory to the brave!'). 
No less suitable for the Futurists' rebellious call, which was quoted by Burlyuk, would be a different meaning of the exclamation: according to the dictionaries by Vladimir Dal' and D.N.Ushakov, it could be interpreted as 'bargehaulers, clear off!' or 'barge-haulers, go to the prow of the ship (and do not prevent us from robbing your boat)!' A Futurist slogan 'Сарынь на кичку!' could have been an order, addressed by the robbers who took hold of a ship on the Volga to the barge haulers dragging their barges along the river, which demanded they gather at the nose of the ship. The sinister nature of this command concealed the fact that those who failed to obey the order and did not go to the appointed place were immediately killed. Whether the exclamation is interpreted as a heroic exhortation or a glorification of the warriors or an intimidating threat, it was adopted by one of the Futurist poets (Kamensky's 'Saryn na kichku' (Каменский 1932) as the title of his poetic collection, as it was in keeping with the Futurists' belligerent manifestos and their feeling of immense superiority over all other artistic traditions.

One of the defining features of the Futurists (Jangfeldt 1976: 27) was the concept of self. In keeping with the militant, riotous self-identification of the Futurists, expressed in their manifestos (cf. Marinetti's statement: 'The essential elements of our poetry will be courage, audacity and revolt'), Mayakovsky's poem 'I and Napoleon' ('ЯиНаполеон', 1915) represents the poetic persona simultaneously as a leader in a battle ('Я полководец и больше', 'I am a leader and more') and as Napoleon's counterpart, stronger and better than the French Emperor, who was doomed to failure because of his imperialistic ambitions: 'Сегодня я - Наполеон!... / Сравните: я и он!', 'Today I am Napoleon... Compare: Me and him!' The theme of riot in this poem comes to a crescendo with Mayakovsky's desire to fight the 'sky's tyrant' and his self-confidence that he has the power to destroy it: 'Через секунду / встречу я / неб самодержца, - / возьму и убью солнце!/ Видите!/ Флаги по небу полощет. / Вот он!/ Жирен и рыж. / Красным копытом грохнув о площадь, / въезжает по трупам крыш!', 'In a moment / I shall meet / the emperor of the skies - / I shall take and kill the sun! / You see! / He is rinsing flags in the sky. / Here he is! / Fat and ruddy. / Stamping his red hoof on the square, / Riding in over the corpses of roofs'.The poet identifies the sun as a monarch, the emperor, who is fat and presumably content and willing to trample over 'corpses' in order to ride out either into battle or on a parade. The parallel between the sun and the Tsar, which Mayakovsky implies, is self-evident, especially if the date of the poem's composition, 1915 (two years before the Russian Revolution), is taken into account. Through associating himself with a blood-thirsty leader and a fighter against the imperialistic regime, Mayakovsky tightens the parallel which he, as member of the Cubo-futurists, formed with political revolutionaries.

Fighting against the sun was a favourite theme of the Futurists' art: two years before Mayakovsky's poem 'I and Napoleon' three Futurists composed an opera called 'Victory over the Sun' ('Победа над солнцем'): the text was written by Alexey Kruchenyh, the music by Mikhail Matyushin, and decorations by Kazimir Malevich (Матюшин 1989: 130). The work of the three Futurists was not just a co-authorship but a 'synthesising mutual enrichmen twofold, music and form' (Крученых 1999). Each of the authors used his own means to achieve the novel: Malevich used supremacist designs, Kruchenyh composed ostensibly meaningless texts ('заумь'), MatyushinthroughthedissonancesofhismusiccomposedinstarkcontrasttoVerdi's operas (Толкачева 2005: 126132).Kruchenyh, Matyushin and Khlebnikhov composed their opera in order to glorify the idea of constructing new future, which could only be built after the demolition of the past. The victory over the sun ('The sun is lying at our feet murdered', 'Лежитсолнцев ногахзарезанное!') symbolised the triumph of the Futurists over the old world: as was pointed out by Mikhail Matyushin, "the whole Victory over the Sun is the victory over the old conventional idea of the sun as "beauty", "вся «ПобеданадСолнцем» естьпобеданадстарымпривычнымпонятиемосолнцекак “красоте”" (Матюшин 1989: 132). The title of the opera echoes ideas of the Italian Futurists expressed in their manifesto, 'To Kill the Moonlight' (1911), which proclaimed the death of 'the old European sun' and the advent of the epoch of 'electrical moons' and 'futuristic aeroplanes' (Günther 1987: 1012-1017) and is in keeping with Marinetti's eleventh statute: 'We will sing of the great crowds agitated by work, pleasure and revolt, $<\ldots>$ the nocturnal vibration of the arsenals and the workshops beneath their violent electric moons, $<\ldots>$ the gliding flight of aeroplanes whose propeller sounds like the flapping of a flag and the applause of enthusiastic crowds' (Marinetti 1911).The victory over the sun can be understood as the triumph of progressive technology of the future (electricity and aeroplanes) over the old laws of natural order (the sun) but it can also imply a poetic victory over 'the sun of Russian poetry', i.e. Pushkin, whom the Futurists have been so long and so unsuccessfully trying 'to push from the Ship of Modernity'(Terras 1985: 33-40).

The Futurists' rebellion against Pushkin does not preclude Mayakovsky from developing themes and imagery borrowed from the greatest of the Russian poets. The Futurist poet establishes an intertextual dialogue with Pushkin in his treatment of the theme of a poet and the crowd, most vividly expressed in Pushkin's poem 'A poet and the crowd' ('Поэтитолпа', 1828) with a symbolic epithet from Book VI of Virgil'sAenead (257) 'Procul este, profani': 'A poet was plucking his inspired lyre with his stray hand. He sang - and around him, cold and haughty, profane people were listening senselessly', 'Поэтполиревдохновенной / Рукойрассеяннойбряцал. / Онпел ахладныйинадменный / Кругомнароднепосвященный / Емубессмысленновнимал'). Like Pushkin, Mayakovsky sets up his persona against the crowd, making him voice the poet's own observations. 
Mayakovsky's lyrical hero expresses his attitude to the crowd in the poem 'Натe!' ('Here you go!', 1913): 'I shall burst out laughing and spit joyfully, / spit into your face' ('язахохочуирадостноплюну, / плюну в лицо вам'). This rude, boorish persona, who is represented as a mass-market entertainer or a street fool acting before the crowd ('кривляться перед вами'), is in an ideal position to observe the society around him and make his voice heard. The poetic persona addresses the bourgeoisie as a collective image, devoid of personality, which symbolizes for Mayakovsky and other Futurists old outdated canons. He speaks out about a bourgeois man represented by means of vivid synecdoche, his moustache and the prosaic cabbage soup which sticks in it ('You here, man, have got cabbage in your moustache, of from half-eaten somewhere, half-finished cabbage soup', 'Вот вы, мужчина, у вас в усах капуста / Где-то недокушанных, недоеденных щей') symbolising the old and, as Mayakovsky and the Futurists viewed them, constrictive traditions. The woman, her real face concealed behind a 'thick glaze of makeup' ('на вас белила густо') and constricted by 'material things' like a shell ('устрицей из раковин вещей'), embodies 'mundanity' ('быт'), the category loathed so much by Mayakovsky in his individual poetic life ('love boat smashed by mundanity', 'любовная лодка разбилась о быт'). The lyric persona of a free-speaking observant individual allows Mayakovsky to display his own self-identity as a universal judge who must and does express his opinion to the people, calling on them to see their own 'shells', to which they are confined, and abandon the bourgeoisie. Mayakovsky's lyric persona opposes himself to the crowd and expresses hatred towards members of the surrounding world who lack the individuality fundamental to the Futurist conception of 'self'.The selfidentification of the Futurist poet with a lyric persona, who is very much like Mayakovsky himself, and from whose point of view the poems are spoken, also reveals the sense of intense loneliness and isolation from society.

The Futurist poet's image of 'self' in his prerevolutionary poems is of a deeply tragic individual, dissatisfied with his time and society. Using Blok's words, Mayakovsky's self-identity can be called 'an insulted genius' isolated from society and consumed with desire to fight back against it. Mayakovsky's self-identity becomes the subject of conscious self-reflection in his article 'О разных Маяковских', in which the poet identifies himself with a number of personae, trying on different masks: a brazen cynical individual, a cabby, a self-advertiser. All these selfidentifications are linked by a single and very marked desire to stand out from the public and to protest against it. The self-identification with a brazen persona ('I am brazen', ' $Я$ - нахал') is represented through an individual who takes pleasure in wearing his yellow cardigan because it clashes with the dapper suits of all the others and thus stands out visually among the bourgeois crowd ('for whom the highest pleasure is to put on a yellow cardigan and tumble into a gathering of people who nobly preserve modesty and decency under their overcoats, tailcoats and suit-jackets'). Mayakovsky's 'yellow cardigan' becomes an instrument to attract attention. His 'cynical' persona ('I am cynical', 'Я - циник') shows a man who protests against the crowd and physically soils their clothes with his disgust. The poet's self-description as a cabby is also of an individual who clashes with his surroundings, who is too coarse, or rather not bourgeois enough, to fit in the salon of society: 'I am a cabby, who is only just allowed into a parlour when the air becomes heavy with words, hanging like heavy axes, as his profession is not fit for salon dialectics'). Less jarring than the brazen cynical cabby is the self-identification with the persona of a self-advertiser ('I am an advertisement maker', ' $Я$ - рекламист'), which implies an individualist who spends his time 'feverishly looking through every newspaper seeking out his own name' among the thousands of words and names'. Mayakovsky's catalogue of self-identities concludes with a final ' $Я$ - ...', a pronoun left elliptical and meant either for the reader or for the poet himself to fill out with his own poetry: as he wrote in his poem 'Облаковштанах' ('A Cloud in Trousers', 1915): 'And I feel that 'I' is not enough for me', 'Ичувствую- “я” дляменямало'. The Futurist poet's self identity is thus much more than merely a sum-total of the various masks he has been trying on, but this 'more' cannot be clearly identified.

All the various forms of self-identification in Mayakovsky's pre-revolutionary poetry speak of his loneliness and repulsion towards the bourgeoisie. One of them is represented through the mask of a dandy (Stahlberger 1964: 74), which since its appearance in European culture was endowed with associations with Romantic rebellion and its cult of individualism against the norms and traditions accepted in society (cf. Lord Byron's exemplary role or Bulwer-Lytton's 'Pelham' which drew Pushkin's admiration and could have influenced his Evgenii Onegin, who was 'dressed like a London dandy', 'какдендилондонскийодет'). Self-identification with a dandy ideally fitted Mayakovsky and the mood of his 1912-1917 poetry because, as was shown by Stahlberger in the succinct definition of a dandy, 'the dandy as a pure type has three factors, self-creation, self-concealment and alienation from others' (Stahlberger 1964: 74). Mayakovsky's poem 'Fop's cardigan' ('Кофта фата') mentions all three factors: the poet asserts that the garments in question are used to create the image of a 'fop' (self-creation), behind which the poet is hiding his vulnerable soul (self-concealment) and which underlines his alienation from society: 'Along the Nevsky prospect, along its polished lanes, I shall saunter walking like Don Juan and a fop', 'ПоНевскомумира, полощёнымполосамего, / профланируюшагомДон-Жуанаифата'. It is not unlikely that Mayakovsky inherited the image of a dandy from his literary predecessors, Pushkin and Lermontov, famous for presenting their respective heroes, Onegin and Pechorin, as dandies who physically stood out from society and were alien to it (Stahlberger 1964: 74). 
The Futurist poet collides the everyday image of Nevsky Prospekt with that of Don Juan, a literary figure borrowed (together with the image of a dandy) from European culture (cf. Spanish: Tirso de Molina, Italian: Goldoni, French: Molière, German: Hoffmann) or, most probably, from Pushkin's 'Stone Guest' ('КаменныйГость'). The Futurist poet identifies himself with a famous womanizer and a dandy, demonstrating the way in which he, the Don Juan and the fop, stands out among ordinary, everyday society and conflicts with it. The self-identification with a dandy allows the use of various public means of violating social inhibitions, such as extravagance of behaviour, indecency of gestures, the demonstrative intention of shocking the audience, and the recourse to profane, obscene vocabulary, which found its way into the Mayakovsky's poetry before the revolution.

Mayakovsky's characteristically Futurist aggression is directed against a bourgeois, philistine society full of wealthy people who are trying to impress others with posh clothes or are used to buying love for money. In order to illustrate the repulsion he experiences when surveying the bourgeois, mundane crowd Mayakovsky, adopts the poetic persona of an individual deeply at odds with society. It is the bourgeoisie with its banal old-fashioned habits which is the main object of hatred in the Futurist's poetic persona, constantly fighting against the mundanity of everyday life(Наумов 1950: 11). The lines addressed to the poet's beloved in his later poem 'Про это' ('About this', December 1922 - February 1923) show that she is the only creature in the universe whom he agrees to perceive as his ally in the fight against the crowd: 'дажездесь, дорогая, / стихамигромяобыденщиныжуть', 'even here, my darling, fighting with verse the horror of mundanity'. The main weapon in this fight is his poetic art, with the help of which he hopes to destroy the mundanity of life. Thus the voices of the lyric persona and of Mayakovsky merge, becoming the voice of a man whom nobody can understand.

Mayakovsky's lyrical hero feels such intense loneliness and despair that he can no longer identify himself as a human being. He is alone in the crowd and yet must perform before the crowd, as in 'This is how I became a dog' ('Вот так я сделался собакой', 1915): 'the crowd thronged, huge, angry, I got on all fours and began to bark', 'толпа навалилась, огромная, / злая, / я стал на четвереньки / и залаял'. As in all his prerevolutionary poems, the poet and the crowd are set in opposition. The poetic persona is driven to identifying himself with an animal, a dog, to losing his humanity before the crowd ('I cannot express in human ways', 'не могу по-человечьи') and finally expressing his despair, his sense of isolation, his hatred for this crowd, not by means of human speech, which cannot be understood by the indifferent mob, but by barking ('I would have gone ahead / and howled at everything'... I would have stood on all fours and started barking: Woof! Woof! Woof!', 'взял бы / и все обвыл...', / ‘... я стал на четвереньки / и залаял: / Гав! гав! гав!'. This poem exemplifies the way in which Mayakovsky's pre-revolutionary verse is characterized by a feeling of utter despair and isolation, caused by the poet's intense hatred for the bourgeoisie surrounding him(Гончаров 1983: 28). Mayakovsky identifies himself as a solitary outcast, who is isolated from society and is revolted by it.

These feelings of desperation and impending doom are manifested in Mayakovsky's self-identification not as Romantic hero despising the 'crowd' who cannot understand him, but as a victim, or a scapegoat, who must tolerate the cruelty and stupidity of those who surround him (Stahlberger 1964: 68). In 'A Cloud in Trousers' Mayakovsky also identifies his own plight and the inability of the crowd to understand him with that of Christ and his crucifixion: 'This was lifted up in the Golgothas of auditoriums in Petrograd, Moscow, Odessa, Kiev, and there was no one who did not shout: "Crucify, crucify Him!”” ('Это взвело на / Голгофы аудиторий / Петрограда, Москвы, Одессы, Киева,/ и не было ни одного, / который / не кричал бы: / “Распни, / распни его!”').In juxtaposing the two words 'Golgotha' and 'auditorium' (a reference to his journey across Russia in 1913-1914, during which he and his poetry were taunted by the press), each of which denotes a place of torture, Mayakovsky is transforming himself into a Christ figure. He, like Christ, is ready to forgive and love those who have tortured him and yet he, like Christ, receives no pity from the baying mob. By identifying himself as Christ, the poet also seeks to explain his relation to the crowd. His path, if he is like Christ, is the sacrificial path of good and hishatred of the bourgeois and 'mundanity' is justified. Mayakovsky explicitly parallels the crowd who mistreats him with the crowd who called on Pontius Pilate to crucify Christ and to set free Barabbas, a brigand. The poet uses eternal images which have the power to appeal to everybody, in order to reach the highest level of self-representation in his promise to set the whole universe free. Mayakovsky's identifications of himself with martyrs and finally with the Redeemer Himself, who voluntarily sacrifices Himself for the salvation of humanity becomes the extreme expression of his sense of the eternal spiritual loneliness of a poet among the crowd.

The sense of loneliness and isolation in the crowd which cannot be relieved even by the closeness with his beloved permeates all Mayakovsky's pre-revolutionary poems. In the collection of poems 'I' ('Я', 1913) Mayakovsky summarises in two lines the essence of his existence, intense loneliness and a sense of imminently impending and unavoidable doom: 'I am as lonely as the last eye of a person going to the blind!', 'Я одинок, как последний глаз / у идущего к слепым человека!'. The self-identification with an eye, which is also said to be the last ('последний') and therefore the only one, takes upon the poet enormous responsibility as he is confronting a crowd of the blind. He identifies himself with the only bearer of light, the only seeing person in all society. 
These feelings of desperation and impending doom are manifested in Mayakovsky's self-identification as a victim, or a scapegoat, who must tolerate the cruelty and stupidity of the crowd (Stahlberger 1964: 68). Innumerable images which Mayakovsky needs in order to express his poetic self are in constant dialogue with each other and with the poet himself and yet they form an open system, because the poet is much more than the sum total of them all. They are the projection of his poetic self against the background of the historical clash between the old epoch and the new.

The 1917 Revolution marked a substantial change of direction in Mayakovsky's verse, giving him what has been called a 'socio-aesthetic charge' (Гончаров 1983: 19), to fight for new communist ideals together with, rather than separate from, the people, the nation, no longer perceived as a 'crowd'. In his poetry dating between 1917 and 1923, Mayakovsky begins to identify himself as part of the new order of things, viewing his poetry as at one with the Revolution and hence with the community which had been created by it(Гончаров 1983: 17) ('Verse and revolution somehow got united in my head', 'Стихи и революция как-то объединились в голове') and describing the Revolution as a personal experience which roused him to new work ('My revolution. I went to Smolnyi. Worked. Everything, I had to do', 'Моя революция. Пошёл в Смольный. Работал. Всё, что приходилось.' This development in Mayakovsky's self-identity can be seen in the poem 'A Poet Worker', 'Поэт рабочий' (1918), in which he no longer alienates his lyric persona from the masses, but rather displays an admiration for their physical toil(Гончаров 1983: 20): 'And what is verse? It is empty! Surely, youdon'thavegutstowork!', 'А что стихи? / Пустое это! / Небось работать - кишка тонка.' Through the poetic persona Mayakovsky parallels his 'trade' of poetry with those who work 'at the turning machine', 'у токарного станка', affirming a fraternity between himself and the working class, who before he only saw as a 'crowd'(Гончаров 1983:20)' 'I am also a factory. And if I have no pipes, then perhaps it is harder for me without pipes', 'Ятожефабрика. / Аеслибезтруб, / то, может, / мне / безтрубтруднее'. The self-identification with a factory represents the unity of the poet with the working class: they and he are all working on material objects to produce material objects, and his having 'no pipes' makes him not superior but only obliged to work harder. The unity with the people which Mayakovsky feels after the Revolution can be seen in the poem 'To the Workers of Kursk, Who Have Produced the First Ore', 'Рабочим Курска, добывшим первую руду...', in which socialism is viewed as the binding force holding people together by means of a single aim: 'That is how it was: Socialism is a an enthusiastic word! With a flag and with a song we stood on the left, and glory itself descended on our heads', 'Было: / Социализм- / восторженноеслово! / Сфлагом / спесней / становилисьслева, / исама / наголовы / спускалась слава'. There is no need for a blunt affirmation of the people's unity in these lines: instead the plural ending of 'становились' ('stood, became') and the multiple 'heads' ('головы') are enough to indicate the monolith created by the new social order.

The poet identifies himself with a prophet of the new time, he promises to tell everybody about his own role in the new era of socialism: 'I shall tell you about time and about myself', 'Ясамрасскажу / овремени / иосебе'. Нis mission in the new epoch is to purify the people and help to make them better, which motivates the selfidentification with the lowly roles of a cleaner and a carrier of water: 'I am a sanitation worker and a water-bearer, mobilized and called by the Revolution', 'Я, ассенизатор / иводовоз, / революцией / мобилизованныйипризванный'. In the era of socialism the poet can no longer allow himself 'to compose romances' ('строчить романсы'), although it would have gained him popularity: 'But I have been taming myself, standing on the throat of my own song, 'Ноя / себя / смирял, / становясь / нагорло / собственной песне' (conquering not centuries of mistresses but himself). The poetic persona acquires a new self-identification as a propagandist, a ringleader shouting to his audience as if through loud-speakers. Parallel to the poet's acquisition of a new self-identification, the poet's audience also changes: it is no longer represented as a crowd of contemporaries but by generations to come: 'Listen to me, comrades-descendents, a propagandist, a bawler, a ringleader', 'Слушайте, / товарищипотомки, / агитатора, / горлана-главаря'. Thus Mayakovsky's poetic self-identity is dynamic, developing and radically changing after the October Revolution of 1917. After the Revolution the poet's self-identity centres round the figure of a citizen representing the whole of the post-revolutionary community and the Soviet state. In his later poetry, addressed to generations to come, Mayakovsky identifies himself with a 'propagandist' responsible for purifying society, projecting ('bawling') Soviet ideals, represented not as his own but as shared, and using them to cement together a new civilisation, a working member of which he can finally be.

The Futurists' rejection of literary traditions entailed not only abandoning customary poetic content but also related stylistic forms. The proud stance of the poetic persona in Mayakovsky's verse was justified by his experiments with rhythm, rhyme, phonography, declamation, mottos and most importantly with the status of 'the word'(Jangfeldt 1976: 91). The extent of stylistic and lexical denial involved, was expressed in the manifesto, 'A Slap to the Public Taste', in which the Futurists declared their implacable hatred for language as it was used before them ('ненавистьксуществовавшемудонихязыку'). Mayakovsky furthered this sentiment in the manifesto, 'A Drop of tar' ('Капля дегтя'), which he composed alone, without his Cubofuturist companions. He calls for a more decisive 'demolition', rather than 'expansion' of language, on the grounds that it is no longer fit to cope with the mad 
'gallop' of modern life ('To break the old language, which is unable to catch up with the gallop of life') and in particular is propagating the need to view the word as a fundamental and most importantly autonomous entity in poetry ('To establish verbal art as the mastery of the word but not as aesthetic stylisation but as a skill to solve any task in the word', 'A letter on Futurism', Moscow, 1 September 1922(Маяковский 1922: 56). The Futurist movement sought innovation in language, or more specifically in individual words: their positive programme concerned the rights of poets to increase vocabulary with the help of neologisms and new derivatives. Their aim of encoding the word with the help of new denotations was dependent on their linguistic theory: the concept of turning a dead language, which operated stale meanings of set phrases, into a living language with new words having new semantics(Горячева, 2000: 139-147). The Futurists (unlike the Symbolists) sought to strip words down, so as to allow them to be viewed in their own right rather than as symbols for something else. Form and words were deemed by the Futurists to be the fundamental elements of poetry.

In his early poems, Mayakovsky followed the artistic principles proclaimed in his public Futurist manifestos, especially insofar as the use of unexpected collocations is concerned.One of his first Futurist poems, 'Night' ('Ночь'), composed in 1912, combines pictorial description with poetics. The poem takes the form of an extended metaphorusing night and the effects which it has on the surrounding landscape, in order to create an image belonging to a completely different notional sphere (i.e. a gambling-house) (Горбачев 2010: 30): 'Багровый и белый отброшен и скомкан, / в зеленый бросали горстями дукаты, / а черным ладоням сбежавшихся окон / раздали горящие желтые карты.....', 'The scarlet and the white were thrown away and crumpled, / handfuls of ducats were thrown into the green, / And to the black palms of running windows / burning yellow cards were distributed'. The image of a gambling-house in Mayakovsky's poem is not explicitly indicated, instead the poet offers his readers a game, giving sparse and yet post factum clear hints: the green cloth of card tables is depicted in the image of the 'green', into which handfuls of ducats are being thrown ('в зеленый бросали горстями дукаты', 'handfuls of ducats were thrown into the green'), and the cards, which are dealt by other players, are described as the yellow squares dealt into the 'palms' of players, which are reflected on the windows, otherwise dark as it is a rainy ('running') night ('а черным ладоням сбежавшихся окон раздали горящие желтые карты', 'and burning yellow cards were distributed to the black palms of running windows...'). The image of the gambling-house (and of the night) is represented by means of a series of bright blocks of colour, creating the effect more of a painting than of a verbal description: 'Багровый' (scarlet), 'белый' (white), 'зеленый' (green) and 'желтый' (yellow), which is in keeping with the principles of Cubo-futurism. As is well-known, the Cubo-futuristic movement sought to combine Italian futurist poetics and the French artistic principle of Cubism with its bold lines and vibrant colours into a single whole, which would depict the surrounding everyday physical world (in Mayakovsky's 'Night', 'Ночь' it is a simultaneous description of night and of a gambling-house). Thus the Futuristic traditions, in adherence to which Mayakovsky composed this poem, can be discerned in his poetic technique, which can termed the dissociating of metaphor, a stylistic device employed to depict, in visual form only, the surrounding world with its natural phenomena (in this case night) and to denote something entirely dissimilar, that is a gambling-house.

The rhetorical device based on the interplay of metaphors lies at the centre of Mayakovsky's happiest poem about love 'Lyublyu' (November 1921 - October 1922), dedicated to Lilya Brick, the chief Muse of his poetry. The return of the lyrical hero to his beloved is metaphorically implied in the return of a fleet to its native haven or the return of a train to its terminal ('The fleets are all coming to haven, / A train is drawn to the station', 'Флоты - и то стекаются в гавани. / Поезд - и то к вокзалу гонит...'). The syntactic division in these lines coincides with the metrical division, which is unusual for Mayakovsky's poetics based on enjambments. Both initial sentences are short and confined to poetic lines, which enables the poet to draw metaphorically implied parallels between the images (of the fleet and of the train quickly directed to their destinations). Each of these lines starts with a noun ('fleet' in the first line, 'train' in the second) and both metaphoric nouns, used in the function of subjects in the sentences, are followed by a dash, emphasising the briskness of the image (both the fleet and the train are drawn to their points of final destination). Alliteration in the initial syllables of the words closing both sentences ('harbour', 'гавани' - 'draws', 'гонит') establishes a semantic link between the two concepts: the lyrical hero is drawn to his beloved much more strongly than fleets or trains to their harbours and stations: 'And I am all the more to you'because I love! - drawn and bent, 'Ну, аменяктебеиподавней / - яжелюблю! - / тянетиклонит.' The binary formula 'тянет и клонит' ('drawn and bent'), consisting of two synonyms, is used to condense the feeling of the lyrical hero's fascination with his beloved. The same compression of emotion is achieved through coining an occasional word ('подавней', 'all the more'), the comparative degree of the adverb ('подавно'), which, in keeping with the Futurists' principle of breaking the language, violates the norms of Russian grammar, but creates a highly expressive image of the lyrical hero's longing for his beloved: like a ship or a train, he is irresistibly drawn to the object of his love. 
Describing his intense feeling for his beloved, Mayakovsky borrows metaphors from the most renowned Russian poetry and dissociates them from their traditional literary context. An image from the poem 'The Miserly Knight' ('Скупойрыцарь') by Alexander Pushkin, who the Futurists were planning'to throw from the Ship of Modernity',enables Mayakovsky to narrow the universalising scope of his feeling, metaphorically described through the wide perspective of fleets and trains to the world of two humans. His image of the lover in 'Lyublyu' is sharpened through the metaphor of a miser who cannot live without his gold and needs to go down into his cellars to admire it: 'Pushkin's miserly knight descends to feast his eyes on his cellar and to scrape around' ('Скупой спускается пушкинский рыцарь / подвалом своим любоваться и рыться'). The full rhyme of 'рыцарь' ('knight') and 'рыться' ('to scrape around'), which is enriched by alliteration, establishing a phonetic, and hence a semantic, proximity between different parts of speech (verb and noun), emphasizes the metaphoric correlation between the lyrical hero who is attracted by his beloved and a miser who is fascinated by gold. The inherent metaphor in these lines implies a hidden treasure: the poet treasures his love to the point of wanting to hide it so that it belongs to no-one but himself: 'Thus I return to you, my beloved' ('Так я / к тебе возвращаюсь, любимая').The feelings of the poetic persona might imply Mayakovsky's tragic desire to avoid sharing his beloved with anyone else (Lilya Brick was not only married to the poet's friend Osip Brick but had innumerable love affairs which tortured the poet).

The Futurist's favourite poetic device, metaphor, is centered on the image of the cellar where the lyrical hero would like to hide his treasure. The dissociating metaphor prompts the image of a dwelling / home, which for the lyrical hero, is inseparable from his beloved. The opposition of two subjects ('I', ' $я$ ' - 'thou', 'ты' permeating the poem is widened by the introduction of a third subject ('уоu', 'вы'). The poet is addressing the audience, presumably his readers, asking them to share his feelings for his beloved. Just as other people clean themselves, when they return home ('Returning home joyfully. / You scrape dirt off yourself, shaving and washing', 'Домой возвращаетесь радостно. / Грязь вы / с себя соскребаете, бреясь и моясь'), so the lyrical hero is metaphorically cleansed, purified by the return to his beloved: 'So I am returning to you, / Could it be that going to you I am not going home?', 'Такя / ктебевозвращаюсь, - / разве, / ктебеидя, / неидудомойя?!' The rhetorical question, marked in the punctuation, underlines the metaphoric equation of the beloved and home. The verbal repetition of 'возвращаюсь' ('I am returning') and 'возвращаетесь' ('уоu are returning') establishes a key semantic correlation between the adverbial modifiers of place following these verbs 'to you', 'к тебе' and 'home', 'Домой', placed at the beginning of corresponding lines, coinciding with sentences. The correlation between the adverbial modifiers of place, metaphorically uniting the image of the beloved and the image of home, prompts the correlation between the adverbial modifiers of manner, 'sо I', 'так я' and 'joyfully', 'радостно', emphasising the idea of joy at the return to the beloved permeating the whole poem. The only ominous note can be discerned in the line formulating the tragic finality of human existence: 'The earthly ones are taken by the earth's womb', 'Земных принимает земное лоно'. But even the inevitability of the end makes the lyrical hero happy, as it is viewed in the context of his relationship with his beloved as a goal to be aspired to: 'We are returning to our final goal', 'К конечной мы возвращаемся цели'. The poet's attraction to his beloved is as inevitable as the end of human existence: 'So I / to you / am drawing inexorably, / when we hardly part, / when we hardly stop seeing each other', 'Так я / к тебе / тянусь неуклонно, / еле расстались, / развиделись еле'. The repetition of the adverb 'еле' ('hardly') establishes a semantic correlation between the last two verbs in the extract, elucidating the meaning of an occasional nonexisting verb 'развиделись' ('stop seeing each other') through its contextual synonym 'расстались' ('part'). The meaning of the last lines summarises the main idea of the whole poem: the lyrical hero longs for his beloved the very moment they part. He believes in real Love which transforms human existence and realizes that his life changes radically when he meets his beloved.

A dissociating metaphor is used in the expression of joy brought by his feeling of love when Mayakovsky recalls the image of a happy Indian jumping and dancing at his wedding: 'And I am jubilating / Not remembering myself with joy, / I was leaping, jumping like a wedding Indian, I felt so happy, I felt so light', 'А я ликую... От радости себя не помня, / скакал, / индейцем свадебным прыгал, / так было весело, / было легко мне'. The main aim of the dissociating metaphor is to reveal the essence of love and its role in the life of the lyrical hero. The lyrical hero's true love is shown as destiny, more powerful than the lyrical hero himself (cf. the metaphor of a girl playing with the poet's heart as with a ball, in the seventh part of the poem 'Lyublyu'). For the lyrical hero it becomes almost impossible to bear his heart so full of love (as is shown in the eighth part of the poem, entitled 'Impossible', 'Невозможно'). The lyrical hero's heart is the key metaphor present in all parts of the poem: 'Anatomy has gone mad with me. / Entire heart is resounding universally', 'На мне ж с ума сошла анатомия. / Сплошное сердце гудит повсеместно...' The lyrical hero's heart is metaphorically viewed as so huge that, contrary to the laws of anatomy, it encompasses the whole universe. The metaphor of the heart is dissociated from its traditional literary use and is placed into a highly personal, jubilating, triumphant context: 'Mine is this heart, / I admire my own heart', 'Мое это сердце, / любуюсь моим я'. In this line, as if enclosing the lyrical hero's feeling with the repetition of the possessive pronoun ('mine', 'мое' - 'ту', 'моим'), the lyrical hero's heart becomes the object of admiration because it is full of love for his beloved. 
The jubilation of the lyrical hero is motivated by his return to the woman he loves. The accent falls on his own persona; his admiration directed not on the object of his love but on his own poetic universe is an innovation brought by the Futurist poet into the traditional themes of lyrical poetry. The introduction of the innovative device of the dissociating metaphor is in keeping with the poet's own declaration ('Novelty, novelty of material and device are obligatory for each poetic work... Institutions responsible for educating masses must shake up the teaching of aesthetic old junk'). The novelty of the subject and the novelty of poetic technique are united in the poet's vision of the future of Russian literature.

Mayakovsky wrote his 'How to make verse' in response to those who demanded new text- instead of the old ones he criticized: 'You only destroy and do not create anything new! Old textbooks are bad, and where are the new ones? Give us the rules of your poetics! Give us the text books!'. Breaking away from the old, Mayakovsky and the Futurists were able to offer new text books similar to 'How to make verse' to their audience in place of what was offered by the readers of old poetry. Thus Mayakovsky's participation in the Russian Futurist movement directed against traditional canons ('I have often had if not to break, then to discredit the old poetics'), enabled him to find innovative poetic forms in which he expressed new ideas and tackled new poetic themes.

In his later poetry, Vladimir Mayakovsky began gradually to depart from the canons of Futurism. In the poem 'Yubileynoe' ('Commemorative', 1924) the poet states that he has rejected his own banners and manifestos and establishes a close intertextual dialogue with the greatest of all Russian poets, Pushkin, who he previously had called to be 'throw[n] from the Ship of Modernity'. In opposition to the views expressed in Futurist manifestos, Mayakovsky's attitude to Pushkin ranges from joy at establishing a personal relationship with him, expressed in the poet's cordial address to an open declaration of love.The idea of poetic equality is developed by the lyrical hero who envisages the construction of his own monument: 'During my lifetime a monument is due to me according to my rank'('Мне бы / памятник при жизни / полагается по чину'). The poetic persona (identified with the author) implies not only the material statue but also the metaphorical eternal monument personified in his own writing 'After death we shall stand close to each other: you on the letter 'P' and I on the letter 'M','Послесмерти / нам / стоятьпочтичторядом: вынаПе, / ая / наэМ'; 'I need to arrange it with you while I am alive', 'Мне / прижизни / свами / сговоритьсябнадо'. However the lyrical hero expresses a highly negative attitude to the posthumous fame embodied in a statue, which can be interpreted as an intertextual allusion to the whole monument poetry tradition made renowned by Pushkin's 'I Have Erected a Monument to Myself Not Made by Hand' ('Я памятник себе воздвиг нерукотворный').

Ekphrastic representations of monuments are contrasted by Mayakovsky with the immaterial monument, though not verbal or poetic, but 'ideological' ('socialism', 'социализм') constructed with the help of the immortal weapon of poetry. The polemical nature of the opposition of the desired and the rejected monument is underlined by the semantics of its attributes: the participle 'построенный' ('constructed', cf. 'exegi' in Horace, 'я памятник себе воздвиг', 'I have constructed a monument to myself' in Pushkin and Derzhavin) and the adjective 'общий' ('common') bring into prominence the shared nature of the poet's monument as opposed to the individual fame of his poetic predecessors. The egocentricity of the monument poems composed by Pushkin following Horace, is intertextually considered and consciously renounced. The metaphor of the shared immaterial monument is used to reject the idea of creating any monument, albeit verbal or poetic.

In conclusion it can be noted that Mayakovsky's refutation of verbal monument poetry goes far beyond the requirements of the Futurist movement. His innovations in the area of poetic semantics and form are manifested in his introduction into Russian verse of original themes (glorifying the revolution and the new socialist order, rejection of poetic art for the sake of propaganda, sanitation, physical toil, production of ore), of innovative stylistic, rhythmical and visual devices which revolutionized the traditional poetic canons of the time. Mayakovsky creates the rules of a new poetics by introducing into Russian poetry the tonic rhythm, by inventing the lesenka form, new ways of rhyming and widening the scope of poetic vocabulary to include political and revolutionary words indicating the dawn of a new era for Russian literature and culture. Mayakovsky, as one of the most prolific and avid members of the Cubo-futurists, sought to revolutionise art in much the same manner as political revolutionaries desired to overturn the state and form a new socialist community. Mayakovsky's self-identity is dynamic, developing and radically changing after the October revolution of 1917. In his early lyrics (dating between 1912-1917) Mayakovsky identifies himself as a solitary outcast, who is isolated from society and rejected by the bourgeoisie. This eternal spiritual loneliness leads Mayakovsky to identify himself as a scape-goat, then a martyr and finally as the Redeemer himself, who voluntarily sacrifices himself for the salvation of humanity in order to show mankind the true path. After the revolution of 1917 the poet's self-identity centres round the figure of a citizen representing the whole of the post-revolutionary community and the Soviet state. In his later poetry, addressed to generations to come, Mayakovsky identifies himself as a propagandist responsible for purifying society, projecting Soviet ideals and using them to cement together a new civilisation, a member of which he can finally be. 


\section{References}

Jangfeldt, B. (1976). Majakovskij and Futurism 1917-1921. Stockholm: Almqvist \& Wiksell.

Günther, H. (1987). Sieg über die Sonne. Maler als Bühnenbildner 1910-1930. Die Kunst, Bd. 99, H. 12. S. 10121017.

Lynton, N.(1994). Futurism. In: Nikos Stangos, ed. Concepts of Modern Art: From Fauvism to Postmodernism. 3rd edition.London: Thames \& Hudson, P. 90-97.

Marinetti, FilippoTommaso (1911).ManifestodelFuturismo.Rpt.Uccidiamo il chiaro di luna!, uno dei tanti manifesti futuristi di Marinetti. Milano: Edizione Futuriste Di Poesia.

Stahlberger, L.L. (1964).The Symbolic System of Majakovskij. The Hague: Mouton,

Steiner, E.(2009). Programme Notes: Throwing Pushkin Overboard. Victory Over the Sun : Bilingual edition.№ Vol. 1.P. 33-40.

Terras, V. (1985).Handbook of Russian Literature. New Haven: Yale University Press.

Альфонсов, В.Н., (1999). Поэзия русского футуризма. Сост. и подгот. текста В. Н. Альфонсова и С. Р. Красицкого. Санкт-Петербург: Академический проект, С. 5-66.

Гончаров, Б. П. (1983).Поэтика Маяковского. Москва: Наука.

Горбачёв, А.Ю. (2010). Маяковский и футуризм: дооктябрьское творчество поэта. Русский язык и литература, № 9. С. 56-61; № 10. С. 17-28.

Горячева, Т. В. (2000). Иконология кубофутуризма // Поэзия и живопись: Сб. трудов памяти Н. И. Харджиева / Под ред. М. Б. Мейлаха и Д. В. Сарабьянова. М.: Языки русской культуры, С. 139-147.

Гуторов, И.В. (1950).Поэтическое Мастерство В. В. Маяковского. Москва.

Иванов, В.В. (1996).Мнемозина: документы и факты из истории русского театра XX века. Москва: ГИТИС. $286 \mathrm{c}$.

Каменский, В.В.(1932).Сарынь на кичку. Стихи избранные. Москва: Федерация, 112 с.

Каменский, В.В.(1931).Путь энтузиаста. Москва: Федерация,

Ковтун, Е.Ф. (1989). «Победа над Солнцем» - начало супрематизма. Наше наследие. №2.

Крученых, А.Е. (1999). Об опере «Победа над Солнцем». Память теперь многое разворачивает: Из лит. наследия А.Е. Крученых. Сост. Н. Гурьяновой. Berkeley: BerkeleySlavicSpecialties.

Матюшин, М.В. (1989). Русский кубофутуризм: Отрывок из неизданной книги «Творческий путь художника». Наше наследие. № 2 (8). С. 130-133.

Маяковский, В.В. (1961). Письмо о футуризме, 1 сентября 1922 г. Маяковский В. В. Полное собрание сочинений: В 13 т. М.: Гос. изд-во худож. лит., 1955-1961. Т. 13. С. 56-58.

Михайлов, А.Л. (1990). Мир Маяковского. Москва: Современник.

Наумов, Е.И. (1950). Маяковский в первые годы советской власти (1917-1922). Москва: Советский писатель.

Северская, О.И. (2010). Сарынь на кичку! // Русский язык: Журнал. 1-15 марта (№ 5).

Толкачева, Л. И. (2005). Синтез искусств в опере кубофутуристов «Победа над Солнцем». Известия Уральского государственного университета. № 35. С. 126-132. 